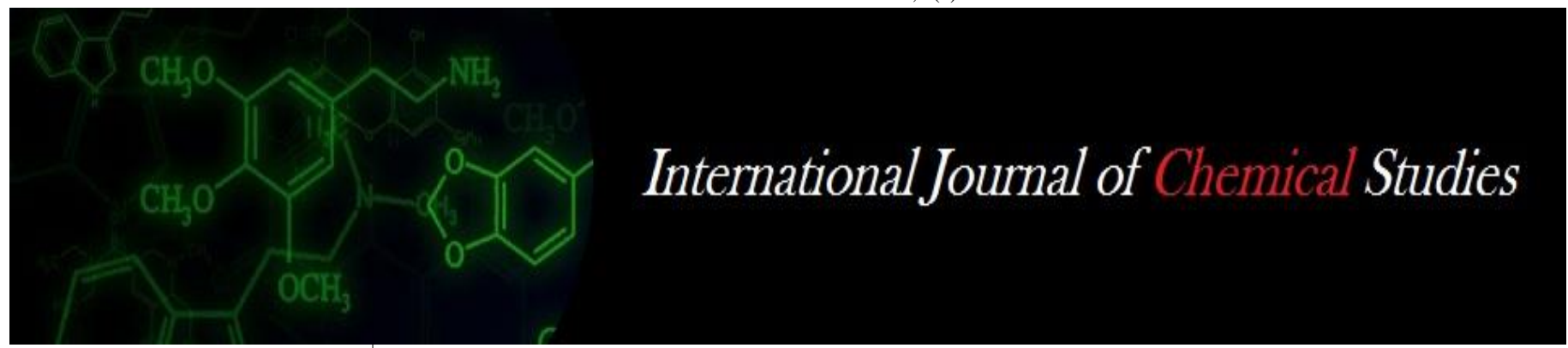

P-ISSN: 2349-8528

E-ISSN: 2321-4902

www.chemijournal.com

IJCS 2020; 8(5): 1222-1224

(C) 2020 IJCS

Received: 22-06-2020

Accepted: 08-08-2020

Angad Singh Rajput

Krishi Vigyan Kendra,

Bhatapara IGKV Raipur,

Chhattisgarh, India

Savita Rajput

Krishi Vigyan Kendra,

Bhatapara IGKV Raipur,

Chhattisgarh, India

Sakshi Bajaj

Krishi Vigyan Kendra,

Bhatapara IGKV Raipur,

Chhattisgarh, India

Pradeep Kashyap

Krishi Vigyan Kendra,

Bhatapara IGKV Raipur,

Chhattisgarh, India
Corresponding Author: Angad Singh Rajput

Krishi Vigyan Kendra,

Bhatapara IGKV Raipur,

Chhattisgarh, India

\section{Effect of improved production technology on yield of chick pea under seed hub project in Balodabazar- Bhatapara district of Chhattisgarh}

\author{
Angad Singh Rajput, Savita Rajput, Sakshi Bajaj and Pradeep Kashyap
}

DOI: https://doi.org/10.22271/chemi.2020.v8.i5q.10471

\begin{abstract}
Chickpea (Cicer arietinum L.) is most important pulse crop in Chhattisgarh State. The productivity of chickpea is low because of non adoption of available technologies by the farmers. Hence last three years seed hub programme going on under krishi vigyan kendra, Bhatapara and coverage large area of farmer's field. First year (2016-17) coverage area and number of village's are 16.80 ha and 06 (Paasid, Gogiya, Marrakona, Alesur, Khapradih, Rajadhar) work with nine farmer's. During the next year (2017-18) coverage area and number of village's are 26.20 ha and 10(Rajadhar, Pendri, Muswadih, Marrakona, Bakulahi, Sanjari, Nawagaon, Devrani, Mopar, Khaparadih) work with nineteen farmer's. During the 2018-19 increase area and number of farmer's 262 and 500 percent, respectively. Now at present this project run under eighteen village's such as Rajadhar, Pendri, Muswadih, Marrakona, Bakulahi, Mopar, Khaparadih, Kodwa, Dhindhini, Jarod, Alesur, Khapradih, Kadar, Limahi, Kairkhata, Kalmidih, Thelki, Gudeliya. Chickpea production was $62.32,242.59$ and $371.74 \mathrm{q}$ with $6.70,9.54$ and $9.60 \mathrm{q} / \mathrm{ha}$ productivity in 2016-17, 2017-18 and 2018-19, respectively.
\end{abstract}

Keywords: Chickpea, farmers, productivity and village

\section{Introduction}

India has taken up the initiative for the establishment of 150 seed hubs for pulses for ensuring timely availability of sufficient quantity of quality seeds. Seed hub project being implemented through the KVKs. It provides to farmers new technology with storage, processing, certification and registration facility. In Chhattisgarh, there are seven centers of seed hub working DES, IGKV, Raipur, 6 are of pulses at KVKs Bhatapara, Rajnandgaon, Kanker, Sarguja, Janjgir-Champa, Kawardha and 1 of oilseeds at KVK Bemetara. Pulses are the important commodities for nutritional securities and the efforts of the KVKs will be helpful to meet demand of pulses as well as to reduce imports. Chickpea is one of the most important pulse crops in India. It is an important constituent of Indian vegetarian diet. It is also an integral part of cropping system for sustainable agricultural production. Inspite of its multifarious advantages, its productivity is poor due to several biotic and abiotic factors. In Balodabazar district Bhatapara, chickpea grown in 2.922 thousand ha area and it productivity is $8.49 \mathrm{q} / \mathrm{ha}$. Chickpea is the $4^{\text {th }}$ largest grain legume crop in the world as well as in Asia. Being a rich and cheap source of protein, it can help people to improve the nutritional quality of their diets. Chickpea is an important source of energy, protein and soluble and insoluble fiber. Chickpea grain contains $60-65 \%$ carbohydrates, $6 \%$ fat and $12-13 \%$ protein. Through symbiotic nitrogen fixation, the crop meets up to $80 \%$ of the soil nitrogen needs, so farmers have to apply less nitrogen fertilizer than they do for other non-legume crops. Chickpea thus are usually grown under stored residual soil moisture with the moisture receding to deeper soil layers with the age of the plants experiencing terminal drought stress. The intensity and the timing of the stress, of course, can vary depending on the previous rainfall, soil type, crop duration and the crop growth. 
Table 1: Improved production technology and farmers practices of chick pea under seed hub project

\begin{tabular}{|c|c|c|c|c|}
\hline S. No. & Technology & Improved Practices & Farmers practices & GAP (\%) \\
\hline 1 & Variety & JG-14 & Local variety & Full gap \\
\hline 2 & Land preparation & Ploughing and harrowing & Ploughing and harrowing & Nil \\
\hline 3 & Pre emergent herbicide & Pendimethalin (@ 2.5 1/ha) & No herbicide & Full gap \\
\hline 4 & Seed rate & $100 \mathrm{~kg} / \mathrm{ha}$ & $120 \mathrm{~kg} / \mathrm{ha}$ & Higher seed rate \\
\hline 5 & Sowing method & Line sowing & Broadcasting & Full gap \\
\hline 6 & Seed treatment & Biofertilizer and Trichoderma & No seed treatment & Full gap \\
\hline 7 & Fertilizer dose (NPK kg/ha) & $5: 10: 0$ & $10: 20: 0$ & Partial gap \\
\hline 8 & Plant protection & Integrated pest management & Indiscriminate application & Full gap \\
\hline 9 & Grading the produce & Grading followed & Not followed & Full gap \\
\hline
\end{tabular}

Technology gap = Potential yield - Seed hub project yield

Yield Extension gap $=$ Seed hub project yield - Farmers yield

Technology index $=\{($ Potential yield - Seed hub project yield $) /$ Potential yield $\}$ x 100

Table 2: Performance of chickpea (JG -14) through demonstration of integrated crop management technologies

\begin{tabular}{|c|c|c|c|c|c|c|c|c|c|c|c|c|c|}
\hline \multirow[t]{2}{*}{ Year } & \multirow{2}{*}{$\begin{array}{c}\text { No. of } \\
\text { farmers } \\
\text { under seed } \\
\text { hub project }\end{array}$} & \multirow[b]{2}{*}{ Area } & \multicolumn{3}{|c|}{ Yield (q/ha) } & \multirow[t]{2}{*}{\begin{tabular}{|c|} 
Percentage \\
increase in yield
\end{tabular}} & \multirow[t]{2}{*}{\begin{tabular}{|c|}
$\begin{array}{c}\text { Technology } \\
\text { gap }\end{array}$ \\
\end{tabular}} & \multirow[t]{2}{*}{\begin{tabular}{|c|}
$\begin{array}{c}\text { Extension } \\
\text { gap }\end{array}$ \\
\end{tabular}} & \multirow[t]{2}{*}{$\begin{array}{l}\text { Technology } \\
\text { index }(\%)\end{array}$} & \multicolumn{2}{|c|}{$\begin{array}{c}\text { Net Return } \\
\text { (Rs/ha) }\end{array}$} & \multicolumn{2}{|c|}{ B:C } \\
\hline & & & \begin{tabular}{|c|} 
Potential \\
yield
\end{tabular} & $\begin{array}{c}\text { Yield under } \\
\text { seed hub } \\
\text { project }\end{array}$ & $\begin{array}{l}\text { Farmers } \\
\text { practices }\end{array}$ & & & & & & & & \\
\hline 2016-17 & 09 & 16.80 & 18 & 6.70 & 5.01 & 33.37 & 11.30 & 1.69 & 62.78 & 39250 & 25105 & 4.50 & 2.37 \\
\hline 2017-18 & 19 & 26.20 & 18 & 9.54 & 6.86 & 39.06 & 8.46 & 2.68 & 47.00 & 42338 & 30170 & 5.00 & 3.30 \\
\hline 2018-19 & 54 & 60.98 & 18 & 9.60 & 7.00 & 42.86 & 8.40 & 2.60 & 46.67 & 45945 & 32400 & 5.35 & 3.47 \\
\hline Average & 27.33 & 34.66 & 18 & 8.61 & 6.29 & 38.55 & 9.39 & 2.32 & 52.17 & 42511 & 29225 & & 3.05 \\
\hline Total & 82 & 103.98 & - & 25.84 & 18.87 & - & - & - & - & - & - & - & - \\
\hline
\end{tabular}

\section{Materials and Methods}

The chickpea grown under seed hub project on farmer's field to demonstrate the impact of integrated crop management technology on chickpea productivity over three year during rabi 2016-17 to 2018-19. The integrated crop management technology comprised the improve variety, proper tillage, seed rate, pre emergent herbicide application, seed treatment, proper nutrient and pest management (Table. 1). This experiment was conducted to study the technological gap between the potential yield and seed hub projected yield, extension gap between seed hub projected yield and yield under existing practice and technology index. The yield data were collected from both the seed hub project and farmers practices by random crop cutting method and analyzed by simple statistical tools. The technology gap, extension gap and technology index (Samui et al., 2000) ${ }^{[2]}$.

\section{Result and Discussion}

During the study period it was observed that the seed hub projects have increased the yield over the farmers practices (Table 2). Full gap observed in most of production technology was the reason of not achieving potential yield. Farmers were not aware about recommended technologies

\section{Yield}

The results revealed that due to seed hub project on chickpea an average yield was recorded 8.61q/ha under seed hub project as compared farmer's practices (6.29 q/ha). The highest yield in the seed hub project was $9.60 \mathrm{q} / \mathrm{ha}$ during year 2018-19 and in farmer's practices, it was $7.00 \mathrm{q} / \mathrm{ha}$ in the same year and lowest yield was recorded in the year 201617.The average yield of chickpea increased by 38.55 percent. The result clearly indicate that the higher average seed yield in seed hub project over the years compared to local check was due to knowledge and adoption of full package of practices i.e. appropriate varieties such as JG 14, timely sowing, seed treatment with bio fertilizers rhizobium spp and phosphorus solubilizing bacteria (PSB) Trichoderma @ 4 $\mathrm{g} / \mathrm{kg}$ of seed, use of balance dose of fertilizer, method and time of sowing with proper spacing, timely weed management, need base plant protection and grading of seeds. The above findings were in agreement with the findings of Singh et al. (2014) ${ }^{[3]}$ and Tomar (2010) ${ }^{[4]}$. The higher yield of chickpea under improved technology was due to use of latest high yielding varieties, integrated nutrient management and integrated pest management.

\section{Technology gap}

The technology gap means the differences between potential yield and yield of seed hub project. The seed hub project yield (Table 2), were 11.30, 8.46 and 8.40 q/ha during 2016-17, 2017-18 and 2018-19, respectively. On an average technology gap under three year seed hub project was $9.39 \mathrm{q} / \mathrm{ha}$. The technology gap observed may be attributed to dissimilarity in the soil fertility status, crop production practices and local climate situation.

\section{Extension gap}

Extension gap means the difference between seed hub project yield and farmer's yield. Extension gap of 1.69, 2.68 and 2.60 q/ha (Table 2) were observed during 2016-17, 2017-18 and 2018-19, respectively. On an average extension gap under three year seed hub project was $2.32 \mathrm{q} / \mathrm{ha}$. Which emphasized the need to educate the farmers through various extensions means i.e. adoption of improved production and protection technologies, to revert the trend of wide extension gap. More and more use of latest production technologies with high yielding varieties will subsequently change this alarming trend of galloping extension gap.

\section{Technology index}

Technology index indicates the feasibility of the evolved technology in the farmer's fields. Lower the value of technology index, higher is the feasibility of the improved technology. The technology index varied from 46.67 to 62.78 percent (table 2). On an average technology index was observed 52.17 percent during the three years of seed hub project, which showed the efficacy of good performance of 
technical interventions. This will accelerate the adoption of technical intervention to increase the yield performance of chickpea.

\section{Economic return}

Data in table 2 revealed that the cost involved in the adoption of improved technology in chickpea varied and was more profitable. The cultivation of chickpea under improved technologies gave higher net return of Rs. 39,250/-, 42,338/and 45,945/- ha respectively as compared to farmers practices (Rs 25,105/-, 30170/- and 32,400/- per ha in 2016-17, 201718 and 2018-19, respectively). An average net return and B:C of seed hub project was Rs. 42,511/- ha and 4.95, respectively as compared to farmers practices (Rs 29,225/- ha and 3.05). Similar findings were reported by Singh et al. (2014) ${ }^{[3]}$. The benefit cost ratio of chick pea cultivation under improved practices has higher than farmer's practices in all the years and this may be due to higher yield obtained under improved technologies compared to farmer's practices. This finding was in collaboration with the findings of Mokidue et al. (2011) ${ }^{[1]}$ and Tomar (2010) ${ }^{[4]}$.

\section{Conclusion}

It is concluded from the study that there exists a wide gap between the potential and seed hub project yields due to technology and extension gaps and also due to the lack of awareness about new technology. The seed hub project produced a significant positive result and provided the researcher an opportunity the productivity potential and profitability of the latest technology (Intervention) under real farming situation, which they have been impacting for long time. This could be assessing some of the constraints in the existing transfer of technology system in the district, Balodabazar of Chhattisgarh.

\section{References}

1. Mokidue I, Mohanty AK, Sanjay K. Corelating growth, yield and adoption of urd bean technologies. Indian J Ex Edu. 2011; 11(2):20-24.

2. Samui SK, Mitra S, Roy DK, Mandal AK, Saha D. Evaluation of front line demonstration on groundnut. J Indian Soc Costal Agril Res. 2000; 18(2):180-183.

3. Singh D, Patel AK, Baghel SK, Singh MS, Singh A, Singh AK. Impact of front line demonstration on the yield and economics of Chickpea (Cicer arietinum L.) in Sidhi District of Madhya Pradesh. J Agri Search. 2014; 1(1):22-25.

4. Tomar RKS. Maximization of productivity for chickpea (Cicer arietinum L.) through improved technologies in farmers field. Indian J Natul Produ Resou. 2010; 1(4):515-517. 